\title{
Social Science and Liberal Values in a Time of War
}

\author{
Jeffrey C. Isaac
}

\begin{abstract}
In the immediate aftermath of the attacks of September 11, 2001, President George W. Bush declared a "war on terror," which persists with no end in sight. In this paper, I focus on what these developments mean for social science. How should social scientists deal with the threats to civil liberties that always accompany the outbreak of war? Following the precepts of Max Weber, I argue that the flourishing of social science requires that social scientists take responsibility, individually and collectively, for promoting the liberal values that make our academic practices possible. That implies individual scholarly inquiry into the nature and consequences of the war, individual scholarly affiliation with associations that promote academic freedom, and perhaps intervention by professional associations and their affiliates on behalf of academic freedom and political liberties.
\end{abstract}

n the immediate aftermath of the attacks of September 11, 2001, President George W. Bush declared a "war on terror." Originally labeled Operation Infinite Justice, this effort was quickly renamed Operation Enduring Freedom. Neither label, though, leaves any doubt that this "war" is likely to be protracted, at least as envisioned by its architects in the White House, for whom both the Afghanistan war of 2001-2 and the Iraq war of 2003 ad infinitum are not discrete events but moments in a broader process of reasserting U.S. hegemony. The causes and the political consequences of these actions are complex and beyond the scope of this paper; I will instead focus on what these developments mean for political science, and for social science more generally. How does the experience of living and working during a time of war-especially such a protracted and nebulous war-impinge on social science, and how should social scientists respond to such effects? In particular, how should social scientists deal with the threats to civil liberties that always accompany the outbreak of war?

I argue that the flourishing of social science requires a condition of intellectual and civil freedom that is placed in jeopardy during times of war, and that social scientists - even those committed to the political neutrality of social scientific procedures and judgments-should find this assertion particularly significant. In developing this argument, I draw on the work of Max Weber, who in the midst of World War I penned and delivered "Science as a Vocation," a speech that has come to

Jeffrey C. Isaac is department chair, James H. Rudy Professor of Political Science, and director of the Center for the Study of Democracy, at Indiana University, Bloomington (isaac@indiana.edu). His books include Democracy in Dark Times; Arendt, Camus, and Modern Rebellion; Power and Marxist Theory; and The Poverty of Progressivism: The Future of American Democracy in a Time of Liberal Decline. exercise a profound influence on the self-understanding of modern sociology and political science. Although my chief concern is the relationship, if any, between liberal values and social science during a time of war, I will also examine the broader issue of the responsibilities of social scientists during wartime and ask whether we, individually and collectively, are currently affording these responsibilities sufficient attention.

I proceed from Weber for two reasons. First, he has a great deal to say on the matter. Second, "Science as a Vocation" and "The Meaning of 'Ethical Neutrality' in Sociology and Economics" have come to be regarded as the canonical statements of the themes of scientific professionalism, methodological scrupulousness, and value neutrality. These are themes deeply embedded in our profession. And while each is contestable, I treat them as premises - as many of my colleagues do-and ask what a commitment to them really entails. My argument proceeds by way of four general claims:

- liberal values of civil and intellectual freedom are jeopardized during wartime;

- "Science as a Vocation" and "The Meaning of 'Ethical Neutrality' in Sociology and Economics" were political interventions on behalf of a nuanced, complementary relationship between social science and liberal values that is especially important in times of war;

- this particular relationship is worth taking seriously by all who take the practice and professional identity of social science seriously; and

- taking this relationship seriously has implications that, as social scientists living and working during the war in Iraq and the broader so-called war on terrorism, require us to be attentive and active in support of the liberal values that make our social scientific practices possible.

My argument is thus a form of immanent critique. I delineate why social scientists should defend certain liberal values, 
though I do not contend that they must also act on them. Nor do I argue that the moral validity of liberal values rests only upon social scientific convictions; there are independent philosophical and political reasons why individuals ought to support and defend such values. For this article, however, I am only interested in the distinctive and considerable reasons why we, as political and social scientists, might consider ourselves obliged to do so.

\section{Liberal Values in a Time of War}

The liberal values I am chiefly concerned with here are those associated with broadly construed civil freedoms-the freedoms to inquire, communicate, and publicize (and thereby associate) without fear of state interference or persecution. These values have been classically defended by such writers as Benjamin Constant, John Stuart Mill, John Dewey, Karl Popper, and Isaiah Berlin. They argue that a society that recognizes, codifies, and acts upon such values is pluralistic and capable of supporting a range of opinions, agendas, and lifestyles. With respect to these liberal values, the two greatest dangers to freedom are a tutelary state-especially one seeking to promote ideological goals through intellectual monitoring and restraintand a cultural atmosphere of conformism and fear. While not necessarily universally shared by all citizens, even in universities, these values are given lip service by most members of our society, at least when it suits their purposes to do so.

My first point, then, is simple, but it cannot be repeated often enough: civil freedoms are always precarious in a democratic society-something advanced by Tocqueville among others-but they are especially at risk in time of war. Randolph Bourne's essay "The State," written amid the violent furies of World War I, is perhaps the classic description of a citizenry at war:

War-or at least modern war waged by a democratic republic against a powerful enemy - seems to achieve for a nation almost all that the most inflamed political idealist could desire. Citizens are no longer indifferent to their government, but each cell of the body politic is brimming with life and activity. We are at last on the way to full realization of that collective community in which each individual somehow contains the virtue of the whole. In a nation at war, each citizen identifies himself with the whole, and feels immensely strengthened in that identification. . . . At war, the individual becomes almost identical with his society. He achieves a superb self-assurance, an intuition of the rightness of all his ideas and emotions. ${ }^{1}$

But if war generates a wider circle of allegiance, if it rallies people around the flag and fires patriotic sentiment and civic spirit, it also generates fear and a powerful pressure to conform to the needs of the warring state. Bourne describes the people of a democracy at war as a herd, bound together into a single collective by a primitive sense of fear and a desire for state protection:

Every individual citizen who in peacetime had no function to perform by which he could imagine himself an expression or living fragment of the State becomes an active amateur agent of the Government in reporting spies and disloyalists. . . Minority opinion, which in times of peace was only irritating . . . becomes, with the outbreak of war, a cause for outlawry. Criticism of the State, objections to war ... are made subject to ferocious penalties. . . Public opinion, as expressed in the newspapers, and the pulpits and the schools, becomes one solid block. "Loyalty," or rather war orthodoxy, becomes the sole test. . . . Anything pertaining to the enemy becomes taboo. ... .

Liberal intellectuals and activists were plagued by these threats to liberty throughout the twentieth century. Paradoxically, they often regarded war as a necessary means for defending precisely those liberal values that its modalities endanger. ${ }^{3}$ While I share their concerns, I do not assume that the political science community holds similar liberal moral or political convictions. The profession as a whole comprises scholars unified in the pursuit and circulation of scientific truths. At issues here is not whether liberals ought to be troubled by war's inhibitions of civil freedom, but whether social scientists as such ought to be concerned. I believe the answer to that question is yes, and I turn to Weber to support my explanation.

\section{Weber on Social Science and Liberal Values}

In both "Science as a Vocation" and "The Meaning of 'Ethical Neutrality' in Sociology and Economics" (both dating from 1918), Weber powerfully articulated a basic conviction of modern social science, namely, commitment to a certain conception of value neutrality:

The historical and cultural sciences ... teach us how to understand and interpret political, artistic, literary, and social phenomena in terms of their origins. But they give us no answer to the question, whether the existence of these cultural phenomena have been and are worthwhile. ... To take a political stand is one thing, and to analyze political structures and party positions is another. ${ }^{4}$

For Weber the social scientist qua scientist describes and explains but does not prescribe; truths obtained by social science about how the world operates are veridical, regardless of whether we like them or the world they describe.

Weber's position in "Science as a Vocation" is complicated. He presents at least two arguments on behalf of his general claim about value neutrality. The first is an epistemological argument about the logical difference between descriptive and prescriptive statements and discourses to the effect that no statement about what exists logically entails anything about the desirability of that state of affairs. The second—and more powerful of the two-is an ethical argument about the arrogance and intellectual mendacity inherent in the effort to practice scholarship in the manner of a prophet or political leader. To Weber, such efforts constituted a form of deception and, more importantly, an illegitimate exercise of power. He insists that the authority of the scholar-to inquire, enjoy academic freedom, disseminate one's findings, and teach - rests on training and demonstrated ability to offer valid analyses of the way things work, not on special insight into the meaning of life, the ultimate purposes of individuals or nations, or the policies most in accord with some conception of justice. ${ }^{5}$

Weber never maintained that science, as a vocation, was beyond value. In fact, he insisted that the vocation of science presupposed certain intellectual values, and that the decision to become a social scientist required a commitment to the 
value of understanding the way the world works, in other words, a commitment to the value of seeking scientific truth. Indeed "Science as a Vocation" focuses on just this value-and on the discipline required to cleave to it in the face of such temptations as bureaucratic inertia, the mindless reiteration of banalities, and professional opportunism.

Thus for Weber the point is not that science is free of values; it is, rather, that science is a distinctive kind of intellectual practice, characterized by a distinctive set of intellectual values, and that as such it cannot directly engage in moral prescription. Weber acknowledges that scientists can choose to advance moral or political claims. In doing so, however, the scholar abjures any intellectual authority and acts in a nonprofessional capacity, as a citizen whose words carry no special weight:

The professor should not demand the right as a professor to carry the marshal's baton of the statesman or the reformer in his knapsack. This is just what he does when he uses the unassailability of the academic chair for the expression of political ... evaluations. In the press, in public meetings, in associations, in essays, in every avenue which is open to every other citizen, he can and should do what his God or daemon demands. ... [But] every professional task has its own "inherent norms" and should be fulfilled accordingly. In the execution of his professional responsibility, a man should confine himself to it alone and should exclude whatever is not strictly proper to it-particularly his loves and his hates. ${ }^{6}$

While Weber was averse to social scientists using their authority to privilege strong moral or political evaluations, he was not, as the previous quotation illustrates, oblivious to the values associated with science. Indeed, his writings on the methodology of social scientists are seminal reflections into what we might call the "professional ethics" of social science. Professional ethics, as articulated by Weber, are both political and implicitly liberal. In emphasizing intellectual discipline and the specification and maintenance of the boundaries separating the university-based social scientist and the broader domain of clashing ideologies, Weber was taking a profoundly political stance in 1918 Germany. $^{7}$ One discerns in his essays repugnance and fear of the endemic politicization of university life in post-Bismarck Germany, which was especially pervasive during World War I, when the country was gripped by nationalistic passions. Weber offers a powerful critique of many institutional practices of the German university system (many of which also characterized American universities): the hyperpoliticization of classrooms and academic departments; the use of professional credentials and credentialing to certify some political positions and decertify others; and the use of specious criteria to exclude certain classes of scholars from participation in academic life. (Weber was especially critical of anti-Semitism and the exclusion of socialists. $)^{8}$

Far from defending a status quo ante of social scientific neutrality, Weber sought to establish a novel kind of scientific neutrality through ethical and political means-through aiding and abetting reform of university and disciplinary practices. The autonomy of science was a precarious project. It required an appreciation of distinctive intellectual values and the willingness, indeed the courage, to pursue them, regardless of pecuniary, ideological, or political costs. Weber's basic point is that it is not easy to be a social scientist. Like the Protestant, the social scientist practices a form of worldly asceticism. ${ }^{9}$ This requires more than proper technical training. It demands a professional awareness and responsibility linked to integrity —an integrity that is particularly difficult to manifest in times of ideological mobilization and temptation and of widespread anxiety and fear.

The social scientific values defended by Weber have a decidedly liberal tendency, to the point where it may be accurate to say that they are liberal values. For Weber, as for John Dewey, science is distinguished by certain intellectual habits associated with a "disenchanted" attitude and certain critical methods of investigation, inquiry, criticism, and publicity. It requires the robust exercise of intellectual freedom. Scientists must be allowed to read, write, and publish according to their own intellectual interests and not those of dominant political or economic institutions. They (and their apprentices and students) must also be free to converse and travel, establish libraries, teach courses, and organize conferences. A corollary of these intellectual and academic freedoms is the autonomy of academic and professional organizations and institutions, which must function according to the logic of disciplined scholarly creativity and the law of "may the best argument win."

Weber never worked this out in great detail. Clearly all such autonomies, to the extent they are even imaginable, can only be relative. Yet, in Weber's view, authentic pursuit of the scientific vocation requires forms of freedom that, at best, are precarious results of liberal practice. There is usually justification for taking these freedoms for granted. In a liberal society, social scientists may act as though these freedoms are secure, and in most situations this choice may make perfect sense. However, there may be situations in which the very values of science compel an emphatically political and adversarial stance. The dissident career of the late Soviet nuclear physicist Andrei Sakharov is perhaps the best case in point: Sakharov was driven to human rights activism by his commitment to scientific inquiry and the freedom of movement and expression that it requires. ${ }^{10}$

Beyond the intellectual freedoms central to the scientific method, Weber also argues that social science-as a practice of seeking to describe and explain how social processes and institutions work-has certain ramifications that can plausibly be described as promoting liberal values. In "Science as a Vocation" Weber discusses these in the context of teaching, but it is clear that such teaching can be interpreted in the broad sense-relating to the public dissemination of social scientific knowledge-as well as in the narrow sense of classroom instruction. The first ramification of this position is that the social scientist as teacher promotes the recognition of "inconvenient facts'-I mean facts that are inconvenient for their party opinions. And for every party opinion there are facts that are extremely inconvenient, for my own opinion no less than for others." ${ }^{11}$ Weber seems to suggest here that the effort to explain the workings of the world has a critical 
function, insofar as social scientific descriptions and theorizations are likely to exceed, and call into question, partisan rationalizations and what may be pervasive ideological dispositions. He goes so far as to say that in "compelling" his audience to recognize such "inconvenient facts," the social scientist accomplishes "more than a mere intellectual task," and something that might, metaphorically, be described as a "moral achievement." 12

The second evaluative ramification, linked to the first, is the promotion of what Weber calls "the aim of clarity." Social science, he insists, cannot tell social agents what they ought to do. But in explaining to agents the complex causes and consequences of what they seek to do, it can help them to clarify and adjust their projects accordingly - though it cannot authorize or mandate such clarification or adjustment.

If, for instance, democracy is under discussion, one considers its various forms, analyzes them in the way they function, and determines what results for the conditions of life the one form has as compared with the other. Then one confronts the forms of democracy with non-democratic forms of political order and endeavors to come to a position where the student may find the point from which, in terms of his ultimate ideals, he can take a stand. But the true teacher will beware of imposing from the platform any political position upon the student, whether it is expressed or suggested. ${ }^{13}$

Social science, then, has profound implications for the way social agents understand the relationships between their own moral and political values and the means by which these values might be realized. To practice social science is to engage in an activity, including the disclosure of "inconvenient facts," that requires the exercise of certain foundational liberal freedoms. Social science also serves to enhance the exercise of these freedoms by the citizens of a liberal society. Weber's point is not a logical one, but a methodological one. My point, following from Weber, is that the practice of social science presupposes certain conditions inherent in a liberal society, and that it also has certain effects-for which social scientists are responsible in the same way that all humans are responsible for what they do- that promote the exercise of liberal freedoms by liberal democratic citizens. This does not mean that the practice of social science requires one to avow a liberal civic identity or to embrace liberalism.

Weber, himself a liberal, must have been profoundly aware of this coincidence of social science and liberal values. The logic of a Weberian understanding of social science as a vocation requires us to acknowledge this connection and to attend to its significance. This is especially true in times of war precisely because this is when liberal freedoms are most jeopardized.

\section{The Importance of the Weberian Legacy}

Weber's conception of social science is not without its problems. Many philosophers have argued that the epistemological distinction between social and political facts and moral values is problematic and that discourses of facticity and morality merge in complex ways unacknowledged in Weber's classic essays. ${ }^{14}$ Closer to the heart of distinctively liberal political concerns, Weber's entire account of science as a vocation cen- ters on the practice of the university-based scholar as a specialist in pursuit of specialized knowledge. From this conception flow many of his most important arguments. Yet we know that university-based scholars are not simply specialized researchers but teachers, practitioners of "liberal arts," and in some sense perhaps even civic educators. And from a more Deweyan perspective, in which this pedagogical function is central rather than peripheral to the scientific vocation, one could draw more robust conclusions about the value basis and value implications of social scientific practice.

Nevertheless, with its emphasis on the robust pursuit of knowledge and the academic freedom necessary to publicize and contest scholarly work, Weber's conception of the distinctiveness and autonomy of social scientific practice is both foundational for the modern discipline and profoundly valuable. While social scientific practices conventionally promoted under these auspices are subject to many legitimate forms of criticism, it is hard to take seriously the idea that domains of social life beyond the academy are either freer or more intellectually pluralistic than the current structures and institutions of disciplinary knowledge. The most powerful and compelling intellectual criticisms of social scientific practice are immanent criticisms, emerging from within the disciplines and departments of the academy and seeking to amend rather than replace its distinctive forms of inquiry.

The Weberian view also underscores important principles of academic integrity: the disposition to honor the logic of arguments, the inclination of interlocutors to submit reasons on behalf of claims, and the proscription against judging claims and their proponents in terms of arbitrary aesthetic, moral, or political values. One judges one's colleagues based on the ingenuity and intelligence of their analyses rather than by their race, religion, nationality, political conviction, or personality; one judges one's students based on their disposition and ability to engage and question issues and materials intelligently, regardless of whether they are pleasant, attractive, friendly, or sympathetic to one's own beliefs. Of course, such criteria are not the only measures by which one might judge colleagues, but we know what is likely to happen when academic standards are replaced by emphatically religious, moral, or political ones: intellectual values are debased and political recrimination follows. The Weberian conception of integrity sustains certain forms of academic fairness and civility; it also legitimizes the legal and political autonomy of the university. Insofar as this autonomy plays an important functional role in a liberal society, academic integrity thus serves not only academic and intellectual values but liberal moral values as well.

Finally, a Weberian conception of the scientific vocation sustains the importance of intellectual distinction itself and the corollary importance of ethical distinctions and complexities of ethical judgments. Important philosophical subtleties aside, Weber was absolutely correct to insist that in a modern, disenchanted world, one cannot deduce values from the state of affairs at any given point in time. While it may be tempting to think that certain moments have a self-evident moral significance, or that an outcome will take place simply by virtue 
of its desirability, it is actually "childish" to believe these things, as it absolves individuals of the difficult responsibility of deciding what to think and how to act in a world that does not proclaim its own meaning. For the scholar to purport to have ultimate answers or to be able to instruct students or citizens in what is right and good, or for the scholar to use the classroom or a scholarly publication or association to advance a particular political agenda, is counterproductive and intellectually immoral.

The Weberian view, then, is worth defending. At the same time, as Weber himself noted, there is a danger in the conception of the specialized, university-based, value-neutral scholarthe danger of an ethical complacency associated with a routinized, business-as-usual approach to scientific inquiry. Weber emphasizes that "both enthusiasm and work" are essential to social science. ${ }^{15}$ For him, the specialized work of the social scientist is only authentic when inspired by a passion for inquiry and a commitment to the values and forms of integrity distinct to the scientific vocation. Laziness about the world beyond the academy's hallowed halls and indifference to its function as a source of intellectual enablement or constraint is equally dangerous.

If social science requires the flourishing of certain liberal values and practices in order to thrive, what happens when these liberal values themselves are in jeopardy? Who is responsible for securing them? Under such circumstances, may social scientists function as civic "free riders" or must they act as responsible citizens of the world?

\section{Social Science in a Time of War}

Thus we return to Bourne, and to the least controversial of my observations - that liberal values are placed under duress in times of war. There are at least two mutually reinforcing sources of this pressure. One is the preoccupation with national security and the tendency of political leaders and state agencies to monitor society and police its borders, both geographic and mental, under the guise of this concern. The second is the fear of designated enemies, and of vulnerability in general, that war inevitably engenders in civilian populations. The resulting pressure leads, socially and sometimes legally, to conformity of opinion and a rise in "patriotic" support for flag, country, and, often, God as well. In fact, a case could be made-and here I venture nothing more than an informed guess- that in the wake of 9/11 the media has exacerbated this pressure through its continuous coverage of terrorism-related stories and by providing almost unlimited opportunities for officials of the Bush administration to frame the nature of the "threat" and justify an almost single-minded military response to it.

What does the pressure on liberal values have to do with social scientific values? In what ways does it present any special problems regarding the responsibility of university-based intellectuals in general and social scientists in particular?

The war on terrorism and the current campaign in Iraq represent important and novel developments that cry out for social scientific analysis. If the vocation of the social scientific community is to explain the way the world works, then surely social scientists should mobilize their theories to explain how and why these conflicts are unfolding. Such explanations would no doubt disclose many "facts" that are inconvenient for the Bush administration, its critics, the media, terrorist organizations, rogue states, and clerical ideologues alike. They could also expose the means necessary to achieve the objectives avowed by political actorsstate officials, dictators, terrorists, antiwar protesters, and othersand the likely consequences of employing those means. All of this falls under the general rubric of "relevance."

As social scientists, are we expending sufficient individual and collective resources researching these momentous developments, disseminating the results, and teaching them? Larry Diamond insists that the answer generally is no and that political science owes the world an intellectual debt it is loath to pay. ${ }^{16}$ Such a summary judgment is debatable, both in its premises regarding the debt and in its verdict regarding nonpayment. The Social Science Research Council's volume Understanding September 11 at least offers an example of how diverse social scientists analyze current events. ${ }^{17}$ The papers on the Iraq war by scholars of international relations posted on the Columbia International Affairs Online Web site offer another. ${ }^{18}$

The question of whether social scientists have enough to say about these conflicts is interesting, and worth further consideration. For my argument, however, it is peripheral. The central question is, Have social scientists been sufficiently attentive to the liberal values whose flourishing is necessary to the successful practice of the discipline? To put it another way, Have they, individually and collectively, been oblivious to changes in the political culture and the intellectual climate that bode ill for these liberal values and thus for the very practice of social scientific research? It is possible to identify a range of concerns in which social scientists, as adherents of the scientific vocation, might be imagined to have a particular stake: ${ }^{19}$

- Limitations on the free movement of scholars and students, and, more generally, the persecution (mainly abroad but also in the United States) of scholars and students who are part of an international scientific community

- Surveillance measures that render Internet, library, and bookstore records less secure

- The emergence and strengthening of campus "watchdog" agencies, such as the National Association of Scholars and Middle East Watch, ${ }^{20}$ that monitor campus expression and scholarly publication considered to be unpatriotic, and typically disseminate such information in the form of exposé or the rhetoric of prosecutorial indictment

- The proliferation of books and media commentariesWilliam Bennett's Why We Fight being the most "respectable" 21 that argue that an insufficiently patriotic academy and an overly indulgent liberal education system are responsible for morally disarming our nation at a time of terrorist attack

- The passage of the 2001 Patriot Act—and the drafting of a second Patriot Act-which authorizes an expansion of police powers and, it has been argued by many, places further constraints upon freedom of expression and association 
None of these developments have anything in particular to do with social science per se. They represent predictable forms of legal and cultural closure and, insofar as they endanger liberal values, ought to be of concern to all who subscribe to such values. If my reading of Weber is correct, then social scientists, while not necessarily liberals, are intellectual laborers whose activities require the flourishing of certain liberal values. Therefore, as social scientists, we should be attentive to these antiliberal developments and investigate and perhaps even respond to them in the name of social scientific values.

How might we respond? The most obvious - and ethically and institutionally unproblematic_-response for scholars would be to incorporate the issue of threatened freedoms directly into their teaching and academic writings. This is the scholar's prerogative, and there are ways of doing just this that are consistent with the scruples of value neutrality. Yet even this allocation of intellectual energy seems beyond what most of us consider essential to our scientific inquiries. How much time have most of us spent reading and worrying about the conditions of our own scholarly inquiries and whether they are in jeopardy? Do we understand how recent legal and administrative developments associated with the war on terrorism affect our colleagues and students-especially foreign colleagues and students-libraries, and our legal responsibilities as faculty members? Do we care? To what extent have we integrated a consideration of such matters into the seminars through which we engage in the socialization of our graduate students, the future generation of social scientists?

Another response, still at the level of individual discretion, involves attentiveness to and affiliation with academic organizations whose purpose is to enunciate and defend robust academic freedoms. The American Association of University Professionals (AAUP), for example, formed in 1915 amid anxiety about war and intellectual closure, is the preeminent American professional association of university-based scholars attending to this issue. The premise of the AAUP is that the only way for scholars to attend to and advocate on behalf of intellectual freedoms is by monitoring and disseminating relevant information and by and acting collectively on behalf of scholarly values. The AAUP recently issued recommendations and guidelines on the challenges presented by the war on terror, detailing recent legislative and administrative changes that bear on student privacy issues, immigration and foreign student (and faculty) visa restrictions, library confidentiality policies, and faculty law-enforcement inquiries. The May-June 2003 issue of the AAUP periodical Academe also detailed recent cases in which academic freedom had been called into question by national security-related concerns and offered accounts of how these cases might responsibly be addressed. ${ }^{22}$

In a similar vein, the American Association for the Advancement of Science (AAAS), through its Science and Human Rights Program and under the auspices of its Committee on Scientific Freedom and Responsibility, has organized the highprofile conference, "The War on Terrorism: What Does it Mean for Science." In addition, it has disseminated and publicized this discussion and has sought to promote more extensive examination of these issues.

\begin{abstract}
Science is an international enterprise. To flourish, it requires freedom of thought, expression, and movement, and the freedom to pursue professional activities without interference. Many of the rights and standards set out in the Universal Declaration of Human Rights and international human rights treaties are essential to the conduct of science. ... The AAAS Science and Human Rights Program ... was established in 1977 to give scientists a way to help their colleagues around the world whose human rights are threatened or violated. Mobilizing effective assistance to protect the human rights of scientists around the world remains central to its mission, as well as making the tools and knowledge of science available to benefit the field of human rights. ${ }^{23}$
\end{abstract}

Like the broader AAUP, the AAAS promotes discussion; monitors threats to core values; provides legal assistance in instances where these values are endangered; and even mobilizes solidaristic responses to specific and generalized threats to core human rights, without which scientific inquiry cannot be practicedall in the name of science itself. Yet how many of us are aware of, much less affiliated with or engaged in, these kinds of associations and their activities?

Many universities have responded to recent events with statements articulating the values associated with academic freedom. A case in point is the Statement of Principles drafted by a committee of Indiana University faculty and published by the Indiana University Office of the Chancellor on March 23, $2003 .{ }^{24}$ This document enunciates the importance of the free exchange of ideas; the professorial duty to teach within the parameters of one's courses; the significance of civility in the classroom and on campus; and the need for special attentiveness to the concerns of graduate student instructors and students more generally. The statement can be regarded as a set of guidelines or as a basis for conscientious individual reflection and public discussion about collective faculty and departmental responsibility. How many of us have carefully read, much less seriously discussed, statements such as these? While many aspects of our culture promote the fiction that intellectual inquiry is a solitary activity, and while many of us prefer to act as if this is so (at least as long as it suits us), most of us understand that we work in and through a network of institutions and associations that sustain and promote the scholarly values we both draw on and seek to advance. While these institutions typically take responsibility for the conditions of academic freedom, we scholars all too often regard this matter as none of our business or as a distraction from the real work of science. A division of labor has emerged in which most of us imagine ourselves to occupy a realm of ideational freedom - subject, of course, to the need for grants, research equipment, and research assistants-in which the life of the mind persists independently of the work necessary to support this life, and in which the work of support is regarded as either unnecessary or simply not our proper work.

But if this work sustains the conditions that make science possible, then it cannot be so easily distinguished from the work of science itself. And this is why, as we consider the 
modes of response and forms of affiliation appropriate to the threats imposed by the climate of war, we cannot avoid the context with which we most identify as social scientists-that being the social scientific disciplines themselves. Thus we arrive at what is no doubt a very controversial possibility: explicit intervention on the part of disciplinary professional associations, of the kind exemplified by a statement adopted by the National Council of the American Studies Association at its November 2002 business meeting and published in its March 2003 newsletter: "Intellectual Freedom in a Time of War." The statement outlines recent FBI, Immigration and Naturalization Service (now the Bureau of Citizenship and Immigration Services), and Patriot Act developments that threaten intellectual freedom. ${ }^{25}$ It clearly articulates a commitment to liberal values associated with intellectual freedom, expresses "deep concern" about the fate of these values, and urges "colleagues, university administrations, and elected representatives to repeal those policies, laws, and acts of censorship that endanger intellectual freedom." This is a professional association of universitybased scholars that is making a public statement of moral and political principles on behalf of the association, its members, and the academic field that it claims to represent. It makes a public point, but it also purports to represent and influence the viewpoints of member programs and to mobilize the concern and perhaps even the activity of its members.

The association's statement comes perilously close to crossing the boundaries that separate scholarly and political workboundaries entrenched in the academy that now define the modern social sciences. Article II of the Constitution of the American Political Science Association declares: "It shall be the purpose of this association to encourage the study of Political Science. . . . The Association as such is nonpartisan. . . It will not commit its members on questions of public policy nor take positions not immediately concerned with its direct purpose as stated above." 26 Similarly, APSA's Guide to Professional Ethics in Political Science states that while individual political scientists have the right to engage in political activity, it must be sharply distinguished from their professional work. As the Guide notes, with reference to the disposition of such questions within universities: "Special problems arise if departments or schools endorse or sponsor political activities or public policies in the name of the entire faculty or department or school. ... Departments should adhere strictly to the rule that those faculty members who wish to endorse or sponsor a political position or activity do so in their own names without binding their colleagues. Departments as such should not endorse political positions." 27
And yet the Guide also articulates the centrality of certain ethical commitments. Under the general heading of "Statement on Professional Ethics," for example—after enunciating a professional "conviction of the worth and dignity of the advancement of knowledge," the importance of "intellectual honesty," and the need to "encourage the free pursuit of learning in their students" - the Guide declares: "As colleagues, professors have obligations that derive from common membership in the community of scholars. Professors do not discriminate or harass colleagues. They respect and defend the free inquiry of associates. ... As citizens engaged in a profession that depends upon freedom for its health and integrity, professors have a particular obligation to promote conditions of free inquiry and to further public understanding of academic freedom." 28 These sentiments are echoed in the APSA Constitution itself, in the same Article II, Section 2: "The Association shall not be barred from adopting resolutions or taking such other action as it deems appropriate in support of academic freedom and of freedom of expression by and within the Association, the political science profession, and the university, when in its judgment such freedom has been clearly and seriously violated or is clearly and seriously threatened." ${ }^{29}$

Here we have a set of principles that might be the basis of a serious professional effort on behalf of the liberal values I have termed civic freedoms. Thus far, APSA decision-making bodies have not responded to current events in the manner of the American Studies Association. Is not inconceivable, though, that they might yet do so. Such action would be justified in terms of the professional values central to the association's social scientific identity. Indeed, it would seem to be just such a rationale that supported its August 9, 2003, intervention on behalf of Dr. Saad Eddin Ibrahim, the recently released Egyptian sociologist who had been jailed for his pro-democracy views. Paralleling the more vigorous activism of the American Sociological Association, the APSA intervention, undertaken "on behalf of the scholars and teachers of public and world affairs who are members of the American Political Science Association," clearly rested on the premise that it is appropriate, under certain conditions, for associations to act on behalf of professional values by taking stands on legal or political issues. The association thus implicitly acknowledged that social science does entail a commitment to certain liberal values, as well as a corollary commitment to respond when these values are threatened or violated. ${ }^{30}$

Each of the three kinds of response noted above-individual scholarly interest, individual scholarly affiliation with academic freedom associations, and intervention on the part of 
professional associations and their affiliates-has advantages and disadvantages. There is no reason to imagine that there will ever be a consensus about what to do in a particular case or within any institutional venue. The problem of the civic responsibility of the university-based scholar thus remains one of complex ethical judgment by scholars as people of integrityexactly as Weber imagined. As one moves from individualistic to more collective and institutional forms of response, the danger arises of an excessive politicization of academic institutions, with the corollary fear of the creation of internal political acrimony and conflict. This is a serious threat, and one that lends a measure of credence to the cautionary statements enunciated in professional charters such as the APSA Constitution.

My general inclination is to agree with Stanley Fish, who, in a recent column in the Chronicle of Higher Education, "A University is Not a Political Party," maintained that "academic virtue is the virtue that is or should be displayed in the course of academic activities - teaching, research, publishing. ... [I] t is immoral for academics or for academic institutions to proclaim moral views." ${ }^{31}$ A university, academic department, or professional association is not a political organization, and the recognition of this fact imposes profound constraints on the ways in which university-based professionals ought to view their participation in distinctively academic institutions. Nevertheless, as Fish himself indicates, while it would be dangerous to the legitimacy of academic institutions for them to become directly politicized, they "can and should take collective (and individual) action on those issues relevant to the education missions-the integrity of scholarship, the evil of plagiarism, the value of a liberal education. Indeed, failure to pronounce early and often on these matters would constitute a dereliction of duty." 32

Have we-as individuals, faculty members, and participants in professional associations and discourse- - been overzealous on this score, or have we been in dereliction of duty? I do not believe Weber furnishes us with an answer; nor do I think that there is a single answer to this or any other question of intellectual or moral consequence. I do, however, believe that a serious reading of Weber and a heartfelt consideration of our academic, professional, and intellectual responsibilities force us to consider the importance of the issue. To refuse engagement, in my opinion, is to implicitly call into question the very purpose and value of our vocation as social scientists. If we are not to renounce the value of what we do, then we must recognize the need for a vigorous discussion of the current state of the academy and its connection to the fate of liberal values. Such a discussion, and the forms of engagement that it may lead to, are not superfluous or incidental or a distraction from the more important business of social scientific inquiry. They are an essential part and a necessary condition of such inquiry.

\section{Notes}

1 Bourne 1977, 361.

2 Ibid., 361-62.

3 See Forcey 1961, 221-315; Lasch 1965; Farrell 1975; and Katznelson 2003.
4 Weber 1946, 145.

5 This idea has had a major impact on conceptions of professional ethics in the academy. See, for example, American Association of University Professors 1987. There are, of course, problems with Weber's reasoning. For instance, he insists that the social scientist ought to concern himself with descriptive (and not prescriptive) arguments; yet his speech, offered as the contribution of a social scientist in a social scientific setting, is an emphatically normative one.

6 Weber 1949, 5.

7 Wolin 1981.

8 See Bendix and Roth 1971, 6-55.

9 See Wolin 1981, 412-14.

10 Sakharov 1982; and Sakharov 1990, 267-80.

11 Weber 1946, 147.

12 Ibid.

13 Weber 1946, 145-46.

14 Taylor 1985.

15 Weber 1946, 136.

16 Diamond 2002.

17 Calhoun et al. 2002.

18 Web site is www.ciaonet.org/special_section/iraq/ index_iraq.html.

19 This list of contemporary threats to civil liberties is derived primarily from the Web sites of the American Civil Liberties Union and the American Association of University Professionals. See also Cole 2003.

20 National Association of Scholars, http://www.nas.org/; Middle East Watch, http://www.zmag.org/meastwatch/ meastwat.cfm.

21 Bennett 2002.

22 O’Neil 2003, 21-24.

23 American Association for the Advancement of Science 2004.

24 Brehm 2003.

25 American Studies Association 2003.

26 American Political Science Association 2004.

27 American Political Science Association 1998.

28 Ibid. This text comes directly from American Association of University Professors 1987.

29 American Political Science Association 2004.

30 Putnam and Skocpol 2002.

31 Fish 2003.

32 Ibid.

\section{References}

American Association for the Advancement of Science. 2004. About the science and human rights program. shr.aaas.org/ about.htm.

American Association of University Professors. 1987. Statement on professional ethics. http://www.aaup.org/ statements/Redbook/Rbethics.htm.

American Political Science Association. 1998. A guide to professional ethics in political science. 3rd ed. www.apsanet.org/ pubs/ethics.cfm. 
2004. Constitution of the American Political Science

Association. www.apsanet.org/about/governance/ constitution.cfm.

American Studies Association. 2003. Intellectual freedom in a time of war. American Studies Association Newsletter 26

(1): 16. http://www.georgetown.edu/crossroads/

AmericanStudiesAssn/newsletter/archive/pdf/ asa_March_2003.pdf

Bendix, Reinhard, and Guenther Roth. 1971. Scholarship and partisanship: Essays on Max Weber. Berkeley: University of California Press.

Bennett, William J. 2002. Why we fight: Moral clarity and the war on terrorism. New York: Doubleday.

Bourne, Randolph Silliman. 1977. The state. In The radical will: Selected writings, 1911-1918, ed. Olaf Hansen, 35595. New York: Urizen Books.

Brehm, Sharon Stephens. 2003. Statement of principles. Indiana University Bloomington, March 23. mypage.iu. edu/ sbrehm/speeches/032403.shtml.

Calhoun, Craig, Paul Price, and Ashley Timmer, eds. 2002. Understanding September 11. New York: New Press.

Cole, David. 2003. Enemy aliens. New York: New Press.

Columbia International Affairs Online. Special Section on U.S. Policy and Iraq. http://www.ciaonet.org/ special_section/iraq/index_iraq.html.

Diamond, Larry. 2002. What political science owes the world. PS Online. www.apsanet.org/PS/post911/ diamond.cfm.

Diggins, John Patrick. 1996. Max Weber: Politics and the spirit of tragedy. New York: Basic Books.

Farrell, John C. 1975. John Dewey and World War I: Armageddon tests a liberal's faith. Perspectives in American History 9 (n.d.): 299-342.

Fish, Stanley. 2003. A university is not a political party. Chronicle of Higher Education, January 23. http://chronicle.com/.
Forcey, Charles. 1961. The crossroads of liberalism: Croly, Weyl, Lippmann, and the Progressive Era, 1900-1925. New York: Oxford University Press.

Katznelson, Ira. 2003. Desolation and enlightenment: Political knowledge after total war, totalitarianism, and the Holocaust. New York: Columbia University Press.

Lasch, Christopher. 1965. The New Republic and the war: An unanalyzable feeling. In The new radicalism in America, 1889-1963: The intellectual as a social type, 181-224. New York: Alfred A. Knopf.

O'Neil, Robert M. Academic freedom and national security in times of crisis. Academe 89 (3). www.aaup.org/ publications/Academe/2003/03mj/03mjonei.htm.

Putnam, Robert D., and Theda Skocpol. 2002. Letter on behalf of the American Political Science Association to Mohammed Hosni Mubarak, August 9. www.apsanet.org/ img/about/ethics/ibrahim2.pdf.

Sakharov, Andrei. 1982. The responsibility of scientists. In On Sakharov, ed. Alexander Babyonyshev, trans. Guy Daniels, 205-11. New York: Vintage Books.

- 1990. Memoirs, trans. Richard Lourie. New York: Alfred A. Knopf.

Taylor, Charles. 1985. Neutrality in political science. In Philosophy and the human sciences: Philosophical papers 2, 58-90. Cambridge: Cambridge University Press.

Weber, Max. 1946. Science as a vocation. In From Max Weber: Essays in sociology, ed. H. H. Gerth and C. Wright Mills, 129-56. Oxford: Oxford University Press.

- 1949. The meaning of "ethical neutrality" in sociology and economics. In The methodology of the social sciences, ed. Edward A. Shils and Henry A. Finch, 1-47. New York: Free Press.

Wolin, Sheldon. 1981. Max Weber: Legitimation, method, and the politics of theory. Political Theory 9 (3): 401-24. 